\title{
Literature Review : Pengaruh Kompres Air Dingin Untuk Menurunkan Intensitas Nyeri Pada Pasien Fraktur Tertutup
}

\author{
Triana Asfarotin ${ }^{1 *}$, Nuniek Nizmah Fajriyah ${ }^{2}$, Firman Faradisi ${ }^{3}$ \\ $1,2,3$ Program Studi Diploma Tiga Keperawatan, Universitas Muhammadiyah Pekajangan \\ Pekalongan, Indonesia \\ *email: trianaasfarotin@gmail.com
}

\begin{abstract}
Coldwater compression is one of the non-pharmacological therapies to reduce pain in closed fracture patients. This study highlights the application of cold compress therapy in closed fracture patients by finding research articles from google-scholar. Key words for the search included "kompres air dingin untuk pasien patah tulang" and "patah tulang tertutup" published between 2014 and 2018. Three articles were analyzed. Those articles conclude a similar result. That is, cold water compression effectively reducing pain in closed fracture patients. Hence, healthcare providers are suggested to promote cold water compress therapy as an alternative to reduce pain among closed fracture patients.
\end{abstract}

Keywords : cold compression, pain, closed fracture.

\begin{abstract}
Abstrak
Salah satu terapi non farmakologis untuk menurunkan intensitas nyeri pada pasien fraktur tertutup adalah kompres air dingin. Penelitian ini bertujuan untuk mendeskripsikan penerapan terapi kompres air dingin pada pasien fraktur tertutup berdasarkan tinjauan pustaka. Rancangan karya tulis ilmiah berupa tinjauan pustaka dengan tiga artikel yang diambil dari halaman jurnal Google Scolar dengan kata kunci "kompres air dingin untuk pasien patah tulang" dan "patah tulang tertutup" dengan publikasi tahun 2014 - 2018. Hasil analisis ketiga jurnal tersebut memiliki hasil yang sama. yaitu berkurangnya nyeri saat pemberian kompres dingin. Kesimpulannya terapi kompres air dingin dapat menurunkan intensitas nyeri pada pasien fraktur tertutup. Saran bagi pelayanan kesehatan hendaknya mengedukasi tentang terapi kompres air dingin sebagai alternatif untuk mengurangi intensitas nyeri pada pasien patah tulang tertutup.
\end{abstract}

Kata kunci: kompres air dingin, nyeri, fraktur tertutup.

\section{Pendahuluan}

Fraktur atau patah tulang adalah kerusakan pada tulang atau terputusnya kontinuitas jaringan tulang atau tulang rawan yang umumnya bisa disebabkan oleh benturan keras dari luar atau trauma langsung maupun tidak langsung. Setelah terjadi patahan tulang tersebut biasanya lengkap dan fragmen tulang tersebut bergeser. Fraktur adalah patah, retak, atau pecah seluruh atau sebagian pada tulang dan menyebabkan posisi atau bentuknya berubah (Manurung , 2018).

Menurut Helmi (2013) keluhan utama yang sering ditemukan pada pasien fraktur adalah nyeri. Nyeri adalah suatu kondisi dimana seseorang merasakan sensasi yang tidak nyaman atau tidak menyenangkan yang disebabkan oleh kerusakan jaringan. Nyeri merupakan sensasi ketidak nyamanan yang bersifat individual, nyeri tidak lagi dipandang sebagai kondisi alami dari cidera atau trauma yang akan berkurang secara bertahap seiring waktu, karena nyeri yang tak mereda dapat menyebabkan komplikasi, 


\section{Prosiding Seminar Nasional Kesehatan 2021 Lembaga Penelitian dan Pengabdian Masyarakat Universitas Muhammadiyah Pekajangan Pekalongan}

peningkatan lama rawat inap dirumah sakit dan stress (Helmi 2013 diambil dari E.Purnamasari 2014).

Badan kesehatan dunia world health organization (WHO) 2018, terdapat 5,6 juta orang meninggal dunia dan 1,3 juta orang menderita patah tulang atau fraktur. Salah satu insiden fraktur tertutup yang paling banyak terjadi karena kecelakaan, dimana sekitar $40 \%$ dari insiden kecelakaan menyebabkan kejadian patah tulang atau fraktur. Kejadian fraktur tertutup diwilayah ASEAN memiliki prevalensi sekitar 42,6\% dari insiden kecelakaan. Kejadian fraktur paling banyak sering terjadi pada laki-laki dibandingkan perempuan. Tingginya angka kejadian atau insiden fraktur yang terjadi pada bagian ekstremitas bawah dan tertutup, salah satu penyebabnya karena benturan dengan tenaga yang kuat. Terdapat lebih dari 7 juta orang meninggal karena insiden kecelakaan dan sekitar 2 juta orang mengalami kecacatan fisik. Kejadian fraktur tertutup diwilayah Indonesia sekitar 1,3 juta dengan jumlah penduduk sekitar 265 juta (Chandra, 2018).

Data diatas untuk mengatasi fraktur tertutup dengan upaya farmakologis dan non farmakologis dilakukan berdasarkan pada kebutuhan dan tujuan pasien secara individu. Semua intervensi akan sangat berhasil bila dilakukan sebelum nyeri menjadi parah. Tindakan non farmakologi merupakan terapi yang mendukung terapi farmakologi dengan metode yang lebih sederhana, murah, praktis, dan tanpa efek yang merugikan. Terapi non farmakologi yang dapat digunakan yaitu kompres dingin (Perry and Potter 2014).

Kompres dingin dalam praktik keperawatan digunakan untuk mengurangi nyeri dan edema, karena akan mengurangi aliran darah ke suatu bagian sehingga dapat mengurangi perdarahan. Diperkirakan bahwa terapi dingin menimbulkan efek analgetik dengan memperlambat kecepatan hantaran saraf sehingga impuls nyeri yang mencapai ke otak lebih sedikit. Mekanisme lain yang mungkin bekerja adalah bahwa persepsi dingin menjadi dominan dan mengurangi persepsi nyeri , terapi dingin sangat efektif, mudah dilakukan, cepat, dan ekonomis diantara terapi lain (Fondy, 2012).

\section{Metode}

Karya tulis ilmiah ini menggunakan metode Literatur Review. Literatur Review adalah metode penulisan ilmiah dengan menggunakan cara mengkompilasi, mengklasifikasih, dan mengevaluasi apa yang sudah ditulis oleh penulis pada topik tertentu. Subyek karya tulis ilmiah adalah artikel penelitian yang telah dipublikasikan oleh penelitian sejumlah tiga artikel dengan judul yang sama yaitu pengaruh kompres air dingin untuk menurunkan intensitas nyeri pada pasien fraktur tertutup didapatkan responden sejumlah 61 responden dengan kriteria inklusi dan eksklusi. Kriteria inklusi, terbit dilaman jurnal resmi dibuktikan dengan ada ISSN, menggunakan desain penelitian quasi eksperimen, ketiga jurnal terbit 10 tahun terakhir, artikel full text terdiri dari (abstrak, pendahuluan, metode, hasil, pembahasan, kesimpulan dan saran). Kriteria eksklusi, desain penelitian dari ketiga artikel tidak sama, pengkatagorian hasil uji tidak sama untuk ketiga artikel yaitu katagori (berat, sedang, ringan). 


\section{Prosiding Seminar Nasional Kesehatan Lembaga Penelitian dan Pengabdian Masyarakat Universitas Muhammadiyah Pekajangan Pekalongan

\section{Hasil dan Pembahasan}

\section{Hasil}

Berdasarkan tiga artikel yang telah direview hanya dua artikel yang menampilkan data nilai rata rata mean pada kelompok eksperimen dan kelompok kontrol sebelum dan setelah dilakukan terapi kompres air dingin:

Tabel 3.1 Perbedaan intensitas nyeri pada pasien fraktur tertutup pretest dan posttest dengan kompres dingin pada kelompok eksperimen.

\begin{tabular}{llcc}
\hline Intensitas nyeri & Kelompok & Mean & Pvalue \\
\hline pretest & Eksperimen & 7.00 & 0.744 \\
& Kontrol & 7.27 & 0.704 \\
& & & \\
Posttest & Eksperimen & 5.47 & 0.000 \\
& Kontrol & 7.27 & 0.000 \\
& & &
\end{tabular}

Hasil analisis menunjukan bahwa didapatkan intensitas nyeri pre test pada kelompok eksperimen memiliki rata-rata (mean) 7.00 sedangkan pada kelompok kontrol memiliki rata-rata (mean) 7.27. Hasil post test pada kelompok eksperimen memiliki rata-rata (mean) 5.47 sedangkan pada kelompok kontrol memiliki rata-rata (mean) 7.27. Dilihat dari tabel diatas masing masing nilai Pvalue pre test pada kelompok eksperimen 0.744 , pada kelompok kontrol 0.704 sedangkan nilai $P$ value post test pada kelompok eksperimen 0.000, pada kelompok kontrol 0.000 . Hal ini menunjukan bahwa terdapat penurunan intensitas nyeri sebelum dan setelah dilakukan teknik kompres air dingin, dengan nilai Pvalue $<0.05$.

\section{Pembahasan}

Berdasarkan dari ketiga jurnal penelitian yang telah direview terbukti bahwa terapi kompres air dingin dapat menurunkan intensitas nyeri pada pasien fraktur tertutup menurut penelitian (Sri Kombong, 2018, \& Elia Purnamasari, 2014; Ismonah, Supriyadi, \& Andi Nurchairiah, 2014; Yesi Hasneli, Ganis Indriati).Terapi kompres air dingin ini akan menimbulkan efek analgetik dengan memperlambat kecepatan hantaran saraf sehingga impuls nyeri yang mencapai otak lebih sedikit. Mekanisme lain yang mungkin bekerja bahwa persepsi dingin menjadi dominan dan mengurangi persepsi nyeri. Pada pasien pre operasi sensasi dingin diberikan pada sekitar area yang terasa nyeri, namun pada fraktur post operasi kompres dingin diberikan daerah nyeri yang berlawanan, karena pasien terpasang traksi. Setiap klien akan memiliki respons yang berbeda- beda terhadap area yang diberikan terapi. Respon kulit pada aplikasi dingin 5-12 menit anestesi relatif kulit. Pada umumnya dingin lebih mudah menembus jaringan dibandingkan dengan panas. Ketika otot sudah mengalami penurunan suhu akibat aplikasi dingin, efek dingin dapat bertahan lebih lama dibandingkan dengan panas karena adanya lemak subkutan yang bertindak sebagai insulator (Pcrice \& Wilson, 2006; Novita, 2010) dalam Elia P, 2014.

Kompres air dingin diberikan sesuai kebutuhan atau keperluan dengan waktu 10 15 menit pertama dilakukan secara berulang - ulang pada bagian atau lokasi nyeri 


\section{Prosiding Seminar Nasional Kesehatan Lembaga Penelitian dan Pengabdian Masyarakat Universitas Muhammadiyah Pekajangan Pekalongan}

sampai nyeri berkurang dan hilang. Alat ukur yang digunakan untuk mengukur tingkat nyeri yaitu skala nyeri deskriptif, numerical rating scale, dan faces scale.

\section{Kesimpulan}

Tiga jurnal yang telah dianalisis, dapat disimpulkan bahwa persamaan hasil penelitiannya yaitu terapi kompres air dingin dapat menurunkan intensitas nyeri pada pasien fraktur tertutup. Hasil analisis menunjukan bahwa didapatkan intensitas nyeri pre test pada kelompok eksperimen memiliki rata-rata (mean) 7.00 sedangkan pada kelompok kontrol memiliki rata-rata (mean) 7.27. Hasil post test pada kelompok eksperimen memiliki rata-rata (mean) 5.47 sedangkan pada kelompok kontrol memiliki rata-rata (mean) 7.27. Dilihat dari tabel diatas masing-masing nilai Pvalue pre test pada kelompok eksperimen 0.744 , pada kelompok kontrol 0.704 sedangkan nilai Pvalue post test pada kelompok eksperimen 0.000 , pada kelompok kontrol 0.000 . Hal ini menunjukan bahwa terdapat penurunan intensitas nyeri sebelum dan setelah dilakukan teknik kompres air dingin, dengan nilai Pvalue $<0.05$.

\section{Referensi}

[1] Bahrudin, M. (2017). Patofisiologi nyeri. doi: https://doi.org/10.22219/sm.v13i1.5449

[2] Himma, A. (2015). Kompres hangat dan dingin. Diambil dari http://anni31.mahasiswa.unimus.ac.id

[3] Khodijah, S. (2012). Efektifitas kompres dingin terhadap penurunan intensitas nyeri pada pasien fraktur. Diambil dari http://repository.usu.ac.id

[4] Kombong, S. (2018). Pengaruh kompres air dingin (es) terhadap persepsi nyeri pada pasien fraktur diRSUD Lambuang baji Makasar. Diambil dari http://scholar.google.co.id/

[5] Manurung, N.(2018). Keperawatan medical bedah, konsep mind mapping dan NANDA NIC NOC, cerdas lulus UKOM bidang keperawatan. Jakarta : Trans info media.

[6] Mohammad, (2012). Tanda dan gejaja nyeri. Diambil dari http://repository.unimud.sc.id

[7] Mubarak, W. I., Indrawati, L., \& Susanto, J. (2015). Buku ajar ilmu keperawatan. Jakarta : Salemba Medika.

[8] Purnamasari, E. (2014). Jurnal ilmu keperawatan dan kebidanan, efektifitas kompres dingin terhadap penurunan intensitas nyeri. Diambil dari https://scholar.google.co.id/shcolar?q=efektifitas+kompres+dingin+terhadap+pe nurunan+intensitas+nyeri+pada+pasien+fraktur+di+RSUD+Unggaran\&hl=id\&as _sdt=0\&as_vis=1\&oi=scholar\#d=gs_qabs\&u=\%23p\%3D9sPeSyPQnlw] 


\section{Prosiding Seminar Nasional Kesehatan Lembaga Penelitian dan Pengabdian Masyarakat Universitas Muhammadiyah Pekajangan Pekalongan

[9] Puzianti, A. (2020). Etika penulisan karya tulis ilmiah. Diambil dari https://repository.upi.edu

[10] Rizqy. (2012). Efektifitas stimulasi kulit dengan kompres hangat dan kompres dingin terhadap penurunan persepsi nyeri kala 1 fase aktif persalinan fisiologis.Diambil dari https://scholar.google.co.id/

[11] Rosyidi, K. (2013). Muskuloskeletal. Jakarta: Perpustakaan Nasional. 